\title{
Bibliometric Analysis about the Evolutionary Process of the Internet of Things
}

\author{
Análisis Bibliométrico del Proceso Evolutivo del Internet de las Cosas
}

\author{
S. Hernández-Abaunza ; J. A. Ospina-Ramos iD ; M. Á. Leguizamón-Páez iD \\ DOI: https://doi.org/10.22517/23447214.23401 \\ Artículo de investigación científica y tecnológica
}

\begin{abstract}
The current article presents a bibliometric anaylisis about the contribution made by the Internet of Things (IoT), from its appearance, viewed since social, academic and techonological levels. This analysis was carried out collecting information to a global standard, also it was reviewed more than 60.000 files, which are in the bibliogaphic database Scopus, by means of the techonological tool RStudio. This resource supports the processing of obtained data and whose main idea is to highlight the importance of different scientific and academic cooperations that are developed to national and international standard, which are focused on to research about this topic. It was used the method of information analysis, which consists in study design, data summary, proecessing and display, also the obtained results interpretation since the reckonings made through Rstudio. These results show that the IoT is a very important reference frame to its applicability in many production and services fields to a global level. It is also evident that the United States and China are nations that develop scientific production to a large-scale about the IoT, allocating a big quantity of human, physic and techological resources to such aim
\end{abstract}

Index Terms - Bibliometric Analysis, author, Internet of Things (IoT), Rstudio, Scopus

Resumen-El presente artículo presenta un análisis bibliométrico acerca de la contribución hecha por el Internet de las Cosas (IoT), desde su aparición, vista teniendo en cuenta, los niveles social, académico $y$ tecnológico, este análisis fue desarrollado, recolectando información a nivel global, también se hizo una revisión de más de $\mathbf{6 0 . 0 0 0}$ documentos, las cuales están en la base de datos bibliográfica denominada Scopus, por medio de la herramienta tecnológica Rstudio. Este recurso apoya el procesamiento de datos obtenidos y cuya idea principal es resaltar la importancia de las diferentes contribuciones científicas y académicas que son realizadas a nivel nacional e internacional, que están dedicadas a la investigación sobre este tema. Se utilizó el método de análisis de información, que consiste en un estudio de diseño, recopilación, procesamiento y visualización de datos, también, la interpretación de resultados obtenidos, a partir de cálculos realizados a través de Rstudio. Estos resultados muestran

This manuscript was sent on February 20, 2019 and accepted on November 23, 2020. Este trabajo fue apoyado por la Universidad Distrital Francisco José de Caldas.

S. Hernández-Abaunza está con el Departamento de Tecnología de Microhard SAS. Cl. 72 \#20 03, Bogotá-Colombia. (Correo electrónico: sehernandeza@correo.udistrital.edu.co). que el IoT es un marco de referencia muy importante para su aplicabilidad en muchos campos de producción y servicios a un nivel global. También es evidente que naciones como los Estados Unidos y China desarrollan producción científica a gran escala, sobre el IoT, destinando una gran cantidad de recursos humanos, físicos y tecnológicos para tal fin.

Palabras claves-Análisis Bibliométrico, Autor, Internet De Las Cosas (IOT), RStudio, Scopus.

\section{INTRODUCTION}

$\mathrm{T}$ HE paradigm of IoT arises after years of using Internet as support mechanism on the part of state, private and domestic sectors, which had to associate among them in some moment to obtain better results in their processes and services. These results have been documented by some people and organizations that have written about this model, generating plenty of study and research material, making possible that among them develop quotes and cooperations, allowing that the IoT will be recognized as a tool of inexorable use in almost all the action fields that are inmersed in society.

The scientific publications that deal with the topic of this study have been increasing, this fact has generated importance in the research order, which contribute to the progress of the information and communication technologies (ICT). It is important to highlight that all of this is due to a meticulous work of collecting, analysis and interpretation of data, with the objective of extracting the largest amount of results about the scientific activity named as IoT, such as an bibliometric anaylisis can develop [1].

J. A. Ospina-Ramos está con el Departamento de Tecnología de Microhard SAS. 1. 72 \#20 03, Bogotá-Colombia. (Correo electrónico: jaospinar@correo.udistrital.edu.co).

M. Á. Leguizamón-Páez docente en la Facultad Tecnológica de la Universidad Distrital Francisco José de Caldas. Cl. 68d Bis ASur \#49F - 70, BogotáColombia. (Correo electrónico: maleguizamonp@ correo.udistrital.edu.co). 


\section{IOT SAMPLE APPLICATION}

The entrance and use of technologies related to IoT in different action fields, such as health, industry, energy, defense, among others, have opened a large variety of possibilities to interact joined to more devices and mechanisms, with those that before did not have any control or access, only in a face-to-face form, it means in the same place of location. Now, it does not matter the user geographical location, it is possible to do a large variety of tasks, since to turn on a light bulb, to validate the temperature of a space before going out from our house [3] until to produce a set of a certain product, validating that its quality controls be implemented according to the established policies for that process. This article develops a general analysis to illustrate the reader about the evolution of IoT to a global standard, which will provide a clear repercussion about the growth and impact for the whole community.

In the next fragment it is exemplified as the IoT is applied in simple but essential tasks of a any citizen daily life: $<<$ In the kitchen, an intermittent light reminds me that it is time to take my pills. If I forget to take them, the bottle of pills is scheduled to connect to Internet and send an e-mail to my doctor to tell him about my carelessness. Back home, I see a little sparkle by the corner of one's eye, it is the umbrella handle, that has started to twitch. It indicates, according to the BBC forecast, today it is going to rain >> [4].

To understand more deeply how the devices, which are part of the IoT, work properly, it is important to know the equation that shows the interrelation between the different components of this model that allow its appropriate functioning and it is presented as following (1)[5]:

$\mathrm{D}+\mathrm{S}+\mathrm{C}+\mathrm{A}+\mathrm{I}=$ Internet Of Things

Where $D$ are the devices, $S$ are the sensors (objects that can be used to measure a physical property and convert that information into an electrical or optical signal), $C$ are the controllers (sensor parameter changers), $A$ are the actuators (devices that have the function of acting) and $I$ is internet.

After discussing how the equation works, which was set out previously, it is easy to understand the two samples shown about the medication and the forecast, recognizing that the IoT becomes a technological reference frame of use more essential everytime.

\section{THEORETICAL FRAMEWORK}

The Internet of Things (IoT) is defined as the ability that has any device with Internet connection and this form to generate a service to the world. The vision that can be provided by IoT indicates that instead of existing few and powerful electronic devices that give some kind of functionality to improve the people quality life, there are many peripheral of lower power, that can be added to the big network, achieving with the same daily services in the society, facilitating the works and requirements. It is estimated that by the year 2025 , there will be more than one hundred thousand million of devices linked to the IoT [2].

From the beginning of IoT, it has been establishing a large amount of statistical and mathematical analysis generated about the scientific content, which is produced around this topic, this is named as bibliometry. Such as is indicated by the authors Rojas and De San Antonio, a bibliometric analysis < <it is conceived as a tool especially useful at the moment of design politic strategies from the institutional field, that result in an increase of the international visibility about the scientific research and as a support to design new performance lines in scientific policies $>>[6]$.

The bibliometry is taking a great relevance inside the research field, since it focuses in the calculation and in the quantifiable values on the production field and the scientific information [7]. For a bibliometric analysis will be successful, some authors have determined that the scientific cartography (development and application of computer techniques for the display, analysis and modelling of a wide range of scientific and technological activities in its ensemble) [8] it is the best way.

\section{Methodological Frame}

The methodological design that was applied to carry out a bibliometric analysis in an appropriate and effective form is defined by the following steps [9]:

1. Study design

2. Gathering data

3. Data analysis (software use of bibliometric and statistical analysis)

4. Data display

5. Interpretation and description of obtained findings 
The amount of information that is generated everyday is huge and the scientific cartography is supported in some software for the mathematical and statistical data processing. This research makes a study based on Rstudio software, which is defined as an environment of integrated development (EID) for $R$ (programming language mainly guided to the statistical analysis) which includes a console, a highlighted editor of syntax that admits the direct performance of the code, as well as tools for the outline, history, filtering and administration of the space work [10]. Rstudio will be a basic tool for generating statistics, mathematical calculations and the corresponding validations as to the globalized publications about research around IoT. Specifically, it will be worked with the Bibliometrix library, which is a toold that provides a group of mechanisms for the quantitative research in bibliometry.

From this point, it is started the methodological process described previously, selecting as source of information the bibliometric basis Scopus (step 1), in which it will be filtered the searching with the words 〈<Internet Of Things〉>, that will produce the expected result regarding to the files that have quoted, collaborated and dealt with the topic of this study. After, it will be made an import of references of 61.750 found files about the IoT. It will be generated three downloads of bibliographic Scopus database (files with extension. bib, that will be itemized as following (step 2):

- Years 1970 to 2010: 1875 articles

- Years 2011 to 2019: 59844 articles

- Colombia: 31 articles

Afterwards, it will be done the calling to every downloaded database and it will be implemented the corresponding processes and calculations to the consults that it will be done in Rstudio, by means of stable code lines obtained in mathematical, statistical and graphic operations for the visual and analytic comprehension of results. (step 3). The final product will be reflected in diagrams, tables and images obtained from the computed information.

\section{RESEARCH BACKGROUND ABOUT IOT (YEARS: 1970 TO 2010)}

The obtained results from the first database calculations (years 1970 to 2010) about the IoT research date from the 70's. In fact, it can be proved that there is little information between 1970 (beginning of data collection and study evidences) and 1992 compiled in Scopus. From 1993 it is observed an increase in the scientific production that is growing gradually, having a peak of realizations in year 2000 , totally detaching since this year. In the lapse, comprised between 1970 and 2010, it is possible to count 1875 registered articles, that somehow quoted, wrote or collaborated about IoT, as evidenced in the Fig. 1.

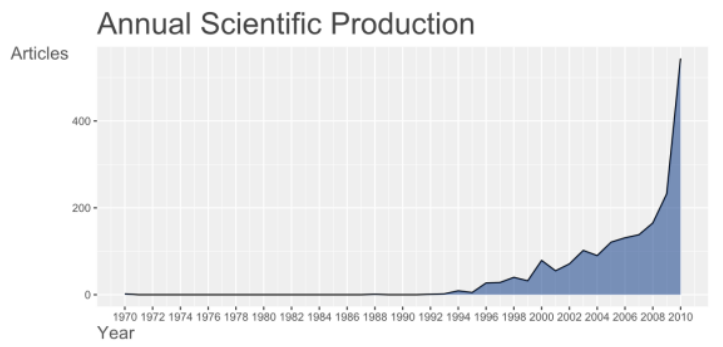

Fig. 1. Diachronic production regarding to IoT between 1970 and 2010. Source: Scopus.

One of the first publications about IoT, that is evidenced, appears in the year 1970 in Greece. It is about its applicartion in the medicine and health fields, with the article $<<$ Health Internet of Things: Metrics and methods for efficient data transfer >>, in which it is made a reference towards the testing that was carried out through monitoring and diagnosis, practiced to the patients by data sensors and links, taking advantage the incursion of some tools which in that moment provided the information and communication techonologies (ICT) )[11]. This paper shows as the rising concept of IoT pretends to become essential for humanity, similar to the medicine, and subsequently it will make and incursion in more activities gradually.

There are not any other reliable data that indicate who have been the most quoted authors per year and who have been the most productive in this registers that they have been inserted in Scopus in this lapse. However, it can be validated that Liu Y is one of the most consulted persons since the beginning of this century and Guinard is who, has publicated a large quantity of articles, towards the second lustrum of XXI century, as it is presented in the Fig. 2:

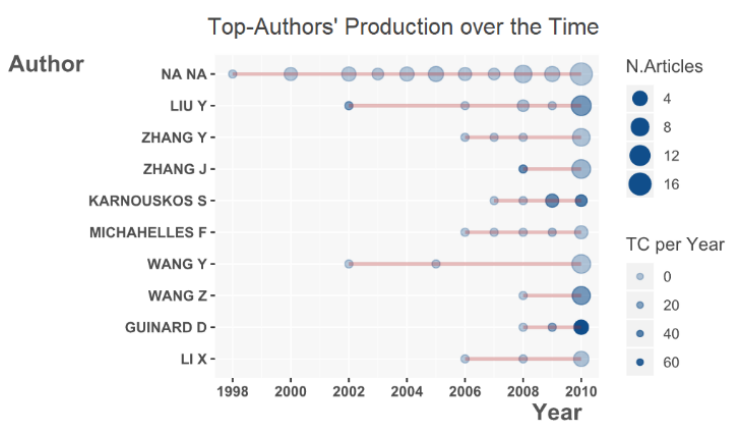

Fig. 2. The most productive authors regarding to research about IoT bertween 1970 and 2010.Source: Scopus.

Among the obtained results after the analysis generated by Scopus, it is possible to identify which are the key words and the number of occasions, where have been quoted in the same words in the referenced files of tha data base that is being worked on. In this case, it can be viewed that there are some 
terms that refer to some relevant considerations of the rising IoT (see Table I). This fact will allow a larger scientific production of this research model.

TABLE I

Most CONSULTED KEYWORDS AT THE BEGINNING OF IOT RESEARCH. SOURCE: SCOPUS

\begin{tabular}{ll}
\hline \hline \multicolumn{1}{c}{ Keyword } & \multicolumn{1}{c}{ Queries } \\
\hline Internet & 891 \\
Internet Of Things & 390 \\
Internet Protocols & 122 \\
Article & 110 \\
Human & 103
\end{tabular}

It can be observed that research at that time was guided towards the Internet rising and how its functioning and evolution spin around the contribution to benefit humanity. Likewise, the term <<Internet of Things >> begins to have importance in the scientific production field.

The connection among authors indicates that at this stage of the evolution about the IoT study, it coexists a quotation system in group that puts together writers and creators of contents to a scientific level and this will spread little by little, as it is represented in the following co-referencing map among authors (see Fig. 3):

\section{Authors' Coupling}

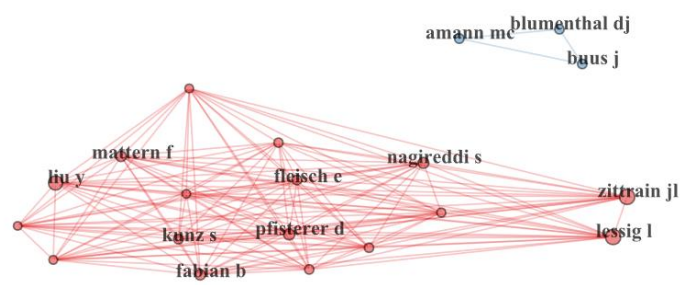

Fig. 3. Bibliographic coupling of authors between 1970 and 2010. Source: Scopus.

It is possible to observe that there is a relation of multiple quotations among authors, this will facilitate the creation of a large connections web between words, texts quotes and reviews, helping the IoT will be recognised as a training topic, learning and analysis continuous, that according to time passes, it will keep itself as recurring source for different sectors to a world level.

It has been evidenced through the reached results with these analyses, that information technology and computing sciences have been disciplines that have focused in the research field and scientific production around IoT, taking some professionals in other knowledge areas to generate interest in the world, developing material in different aspects that have relation to IoT, to solve several issues or to improve the life quality of population. In Fig. 4, it is evidenced that engineering and social science generate an important percentage of material making study about this topic.

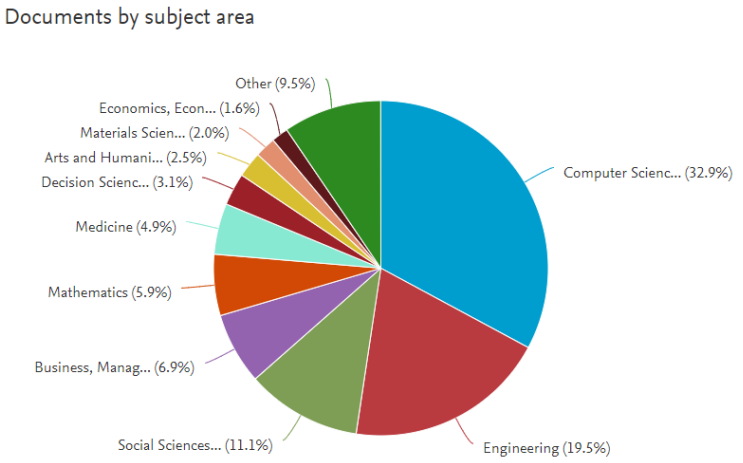

Fig. 4. Areas under investigation of IoT in its beginnings. Source: Scopus.

As it increases the number of publications and quotations referring to IoT, they are obtained the first results regarding to productivity in countries, this is generated by Scopus. In the Fig. 5 , it can be viewed that the United States leads the scientific production with more than 300 files to a local level, and also joined to other countries, validating its status of avant-garde territory in the production field, followed by China with more than 200 texts. Later, China will be cradle of a large management quantity of this type of contents, apart from consolidate itself as one of the territories, which be home to creation center of research texts about IoT (see Fig. 5).

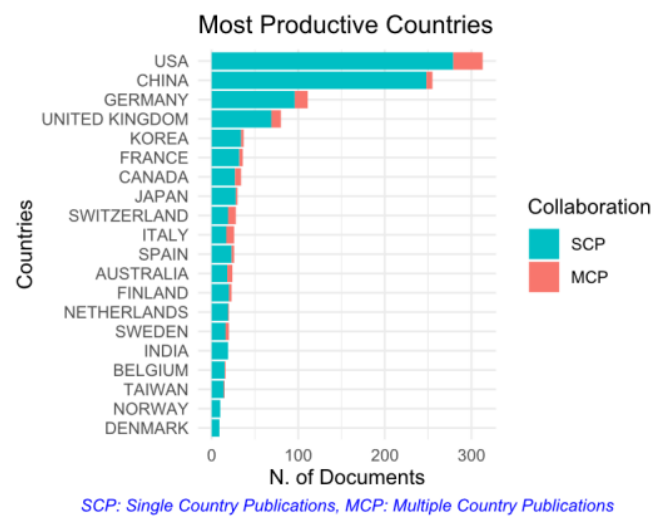

Fig. 5. Most productive countries at the level of research and production in terms of IOT between 1970 and 2010 Source: Scopus.

Recognizing that the publications of these characteristics have increased, evidences that everytime there are more strong ties that link to different countries to the exploration and analysis corresponding to IoT; this will allow a prominent improvement in terms of quality and quantity of studied related to the topic of this analysis. It is important to highlight that the United States 
keeps itself as production axis and scientific cooperation, as it is presented in the Fig. 6:

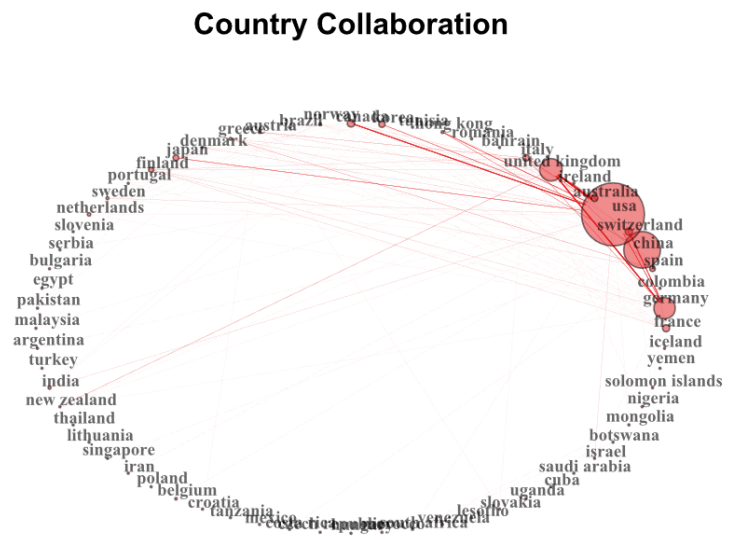

Fig. 6. Scientific collaboration between countries in research and production regarding IoT Source: Scopus.

The expectation of having specifications of a high performance regarding to production and searching about IoT, is shown since year 2000 (see Fig. 1), it is observable that there is a considerable increasing of contents about this technological model, where, it is also, started a tight relation between the recurring to key words (co-recurring), which allow that there will be more affordability to the files and quotations, since through them it is obtained a clearer vision of what it is pretended to expose by the different authors in their appreciations. In the Fig. 7, it is possible to recognize the corelation of key words at the beginning of the research about IoT, discovering that there are some terms, which are familiar to the reader, such as $\langle<$ sensors $\rangle>,\langle<$ technology $\rangle\rangle,\langle<$ internet protocols $>, \quad<<$ information systems $>>, \quad<<$ electronic business $>>$ among others. The closer the distance between two terms, the bigger the relation among them.

Keyword Co-occurrences

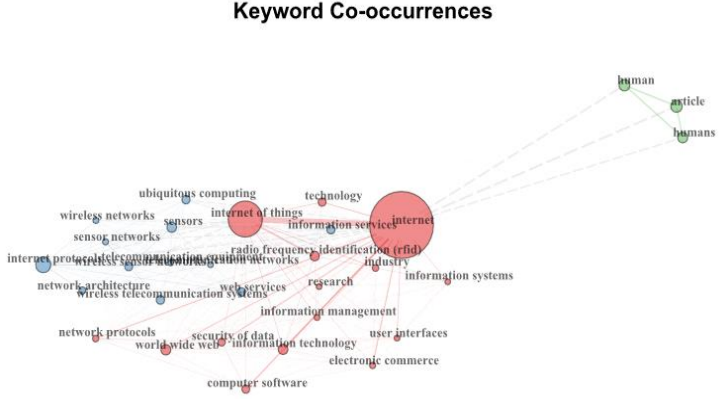

Fig. 7. Co-occurrence network in the nascent research on IOT. Source: Scopus.

Revising the most frequent quotations to some files (see Fig. 8 ), it is evident that there is a tendency to look for texts made in the 2000 decade, probably for the mass expansion that is presented to go deeper in the research about IoT and the importance that is taking in daily life of society.

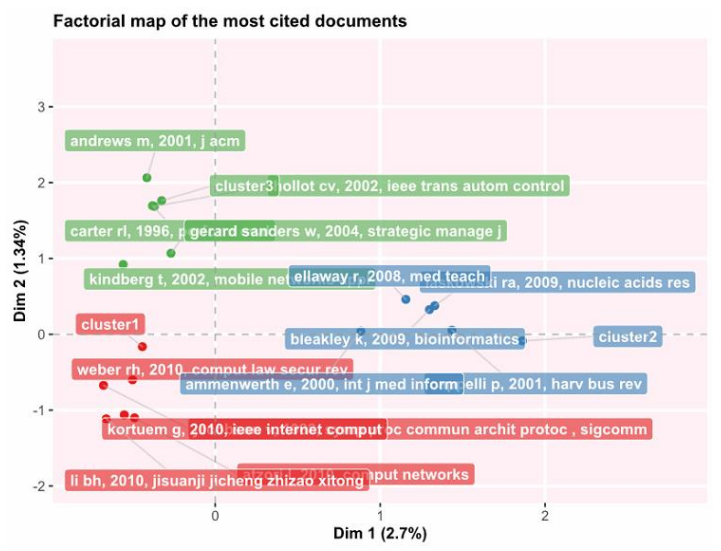

Fig. 8. Most quoted authors at the beginning of IoT research. Source: Scopus.

At this stage, it is possible to visualize the cooperation that is generated by authors, as it can be observed in the Fig. 9, in which they are quoted in a direct way, allowing that the searching process will be more practical. These types of actions will open the door for the bibliometric activity enriches itself and the IoT will be recognized at the same time it progresses in time.

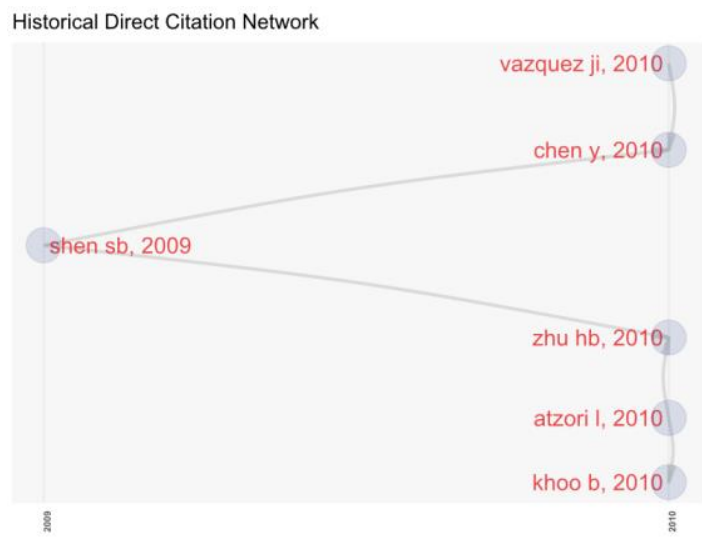

Fig. 9. Network of direct citations between authors at the beginning of the IoT research. Source: Scopus.

\section{CURRENT IoT RESEARCH STATE (YEARS 2011 TO 2019)}

The second bibliometric database, that corresponds to the gathered information between years 2011 to 2019, shows an important increase of files production to a technological level (59844 articles), growing the interest among the international scientific community because of IoT, that inherently uses this paradigm as the main axis in many of its processes and studies. As it can be viewed in the Fig. 10, the quantity of registered articles multiplied significantly, having its highest peak during 
the years 2018, with 17357 files, for the year 2020 there are more than 330 in production phase, waiting for be published.

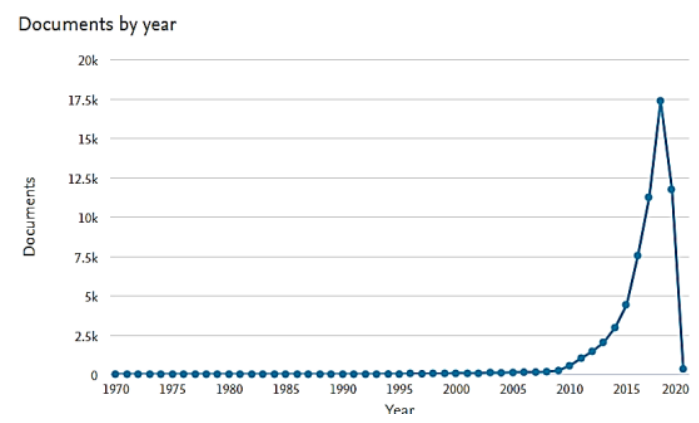

Fig. 10. Documents and studies registered in the Scopus database from 1970 to 2020. Source: Scopus.

The IoT will continue being an instrument with variety of options to use that can be adapted to different set out necessities in any situation, as it expressed by Lee, Kim, Park, Park, Lee and Jeong in their article $<<$ Modulation of surface physics and chemistry in triboelectric energy harvesting technologies $>>$, in which is emphasized how the sensors that are used for the reuse of mechanic energy generated by the piezoelectronic (devices that are used to measure pressure, acceleration, tension or strenght; transforming the readings in electric signals) must consider charateristics of use, charge, communication and adaptability that goes joined to IoT[11].

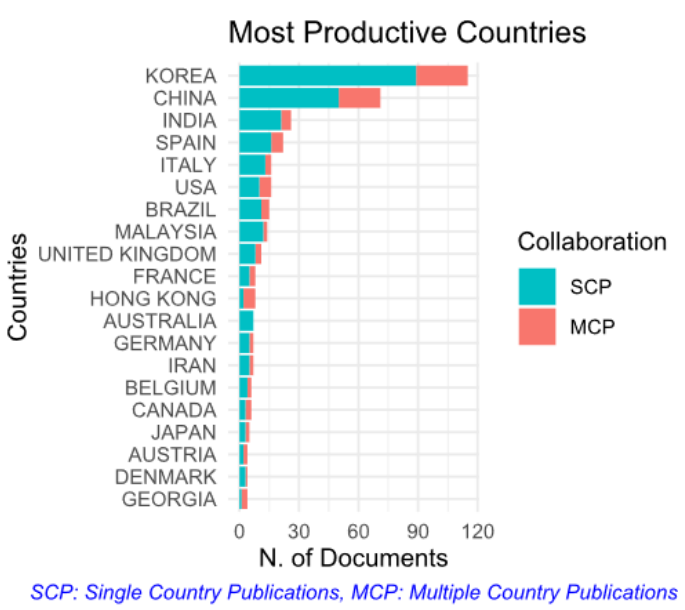

Fig. 11. Most productive countries at the IoT research level in 2019. Source: Scopus.

The Fig. 11 refers to the countries that have generated a higher level, regarding to productivity in research about IoT during the year 2019, it is observable that India and China locate themselves as important potencies in this field

Unlike the beginnings of production and research about IoT, where it is glimpsed as the United States is the main producer of contents and quotations, it is validated that currently the most of the texts come from India, regarding to individual productions and China is at avant-garde in cooperative works with other nations, becoming a very important country about this topic around the world. Taking as a reference the research topic in general terms, as it is shown in Fig. 12:

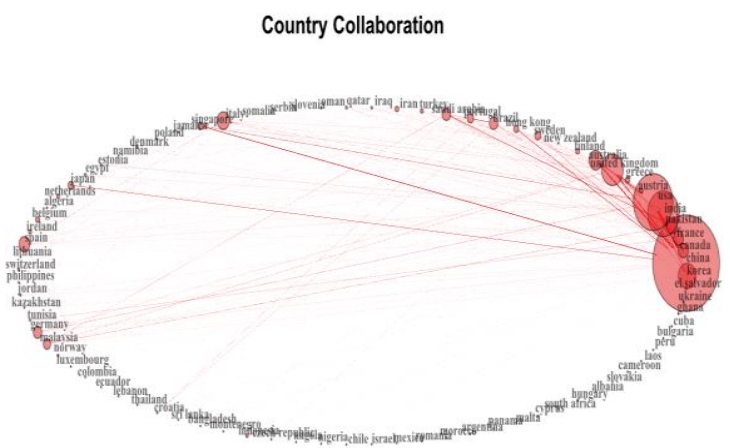

Fig. 12. Scientific collaboration between countries in research and production until IOT in 2019. Source: Scopus.

Likewise, the key words, change as time passes, as it is verified in the Table II, the searching and filtered terms of information are guided to the technological world:

TABLE II

MOST FREQUENTLY CONSULTED KEYWORDS AT THE IOT RESEARCH LEVEL AT PRESENT. SOURCE: SCOPUS

\begin{tabular}{ll}
\hline \multicolumn{1}{c}{ Keyword } & \multicolumn{1}{c}{ Queries } \\
\hline Internet Of Things-IOT & 855 \\
Security & 78 \\
Blockchain & 71 \\
Edge Computing & 70 \\
Cloud Computing & 58 \\
& \\
\hline \hline
\end{tabular}

It is also important to recognize which are the information sources that currently divulge the corresponding material to a research level and scientific production about IoT, they are shown in Table III:

TABLE III

MOST IMPORTANT SOURCES OF DISSEMINATION OF ARTICLES AND WRITINGS ON IOT TODAY. SOURCE: SCOPUS

\begin{tabular}{ll}
\hline \hline \multicolumn{1}{c}{ Source } & \multicolumn{1}{c}{ Articles } \\
\hline IEEE Internet Of Things Journal & 145 \\
Future Generation Computer Systems & 105 \\
Sensors (Switzerland) & 75 \\
International Journal Of Innovative & 51 \\
Technology And Exploring Engineering & \\
International Journal Of Recent & 47 \\
Technology And Engineering & \\
\hline \hline
\end{tabular}

It was made a filter to present which are the areas that have shown more interest to a research level about IoT, as it can be corroborated in the Fig. 13. Most of the articles that have been published are focused towards information technology and in a second place there are some publications that have relation to 
the engineering. These two areas contain more than $60 \%$ of the articles made around IoT. The rest of texts are divided in other branches of knowledge, such as chemistry, social science, mathematics, among others.

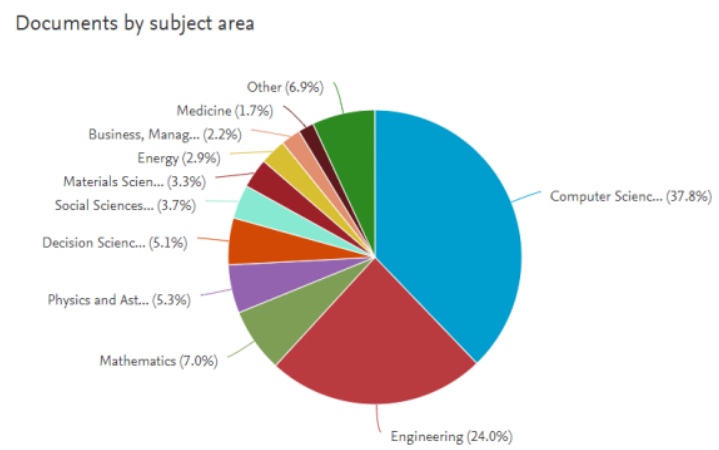

Fig. 13. Research documents by area on IoT. Source: Scopus.

It is considered as something important that bibliometric consults will be generated to the institutions and future researchers study new influenced areas by this paradigm. This fact has increased the interest about how to deal with topics for implementing IoT on several processes and services.

\section{RESEARCH STATE ABOUT IOT IN COLOMBIA}

There are different types of registered research in Colombia, which firstly pretend to show how the IoT provides a high range of services to community, for instance the one evinced by González, Cárdenas and Mendoza [12], where is descrided step by step the implementation of some devices connected to Internet and how they help improve the environmental sustainability through the data measure of water consumption in a bathroom unit (toilet, washbasin and shower) of a house inhabited by 5 people. So, there are 28 articles about different topics, mostly guided to the population comfort in general, such as environment, public transport, agriculture, social innovation, among others, registering notes and quotations corresponding to IoT in Colombia

Referring to the co-quotes (two articles that are quoted in a third one), it is shown that there is a tigh relation among several writers, who are indexed each other. The previous fact happens because of the similarity in the thematic regarding to IoT, what are the various authors dealing with and allow the increasing of research about this topic. Thus, the IoT contributes to a correct indexing of texts on scientific and technological specialities [13]. The higher the quoting frequency, the higher the affinity among authors. The system of co-quotings is shown in the Fig. 14 , in which is presented the proximity among people who have worked in topics related to the IoT in Colombia:
Red de cocitaciones

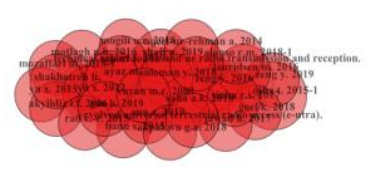

Fig. 14. Coupling between authors at the Colombia level at IoT research level. Source: Scopus.

Likewise, it is presented that little by little the cooperation that Colombia starts to generate to an international level is growing, about research referring to IoT. It is important to highlight that Spain has been the territory that has supported Colombia to become one of the main producers of scientific content in the continental level and in this way, could have a better level of coopetrative work between two territories, as it is noted in Fig. 15 and Fig. 16:

\section{Country Collaboration}

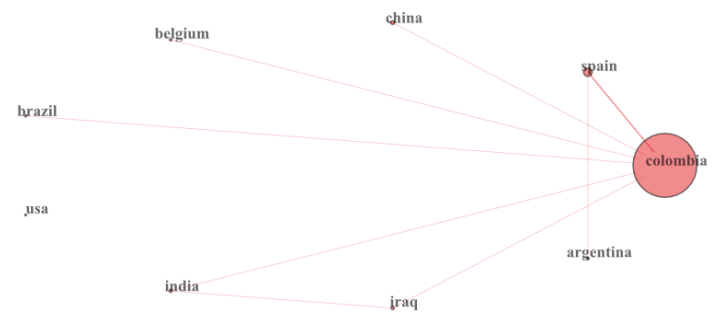

Fig. 15. International collaboration of Colombia at IoT level. Source: Scopus.

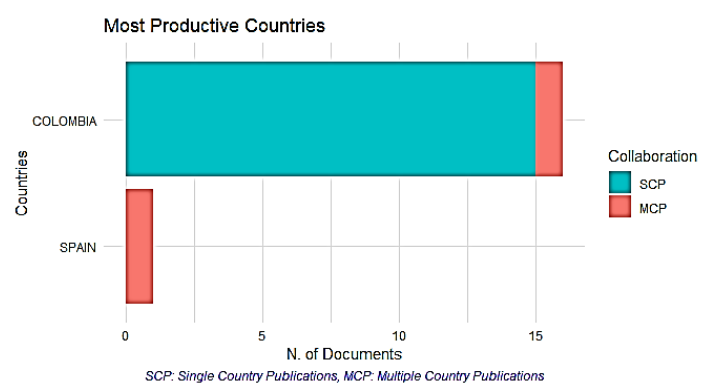

Fig. 16. International collaboration of Colombia at the IoT level. Source: Scopus.

Another clear sample of the IoT use, it is reflected by Coronel, Cuesta and Rico[14] where is shown the importance of making an assembly of sensors for the botanical garden in Cúcuta, which is useful to gather and analyze data about the climate changes and humidity conditions of the ground. This can be consulted from any mobile device, where the users will receive timely alerts about the plant's evolution in the garden and in any eventuality, to be notified opportunely. This system will 
monitor continously the space conditionas and will alert to the users about the changes that need immediate action.

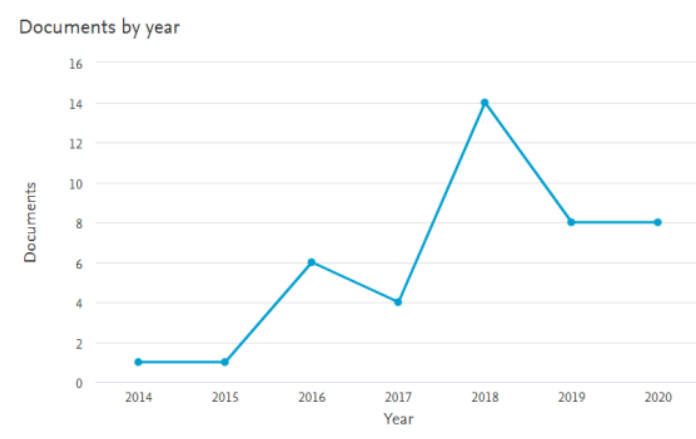

Fig. 17. Research documents per year about IoT in Colombia. Source: Scopus.

In the Fig. 17 it is possible to note that according to the year 2014 , there was only one article, and in less than three (3) years, there was a considerable growth of production and publications about the IoT in Colombia. This growth has the authors and institution interest, of researching how to implement this paradigm towards the improvement of quality life in society. Also, in terms of progress with respect to other countries in the study of thos model.

It is considered as something important the publishing of every article until this time about IoT that come from Colombian researchers, becasue this become the basis for those people who decide to produce future texts of this topic. Hence, these files, it is possible to improve and guide the concepts concerning to thechnology in different action fields, having it as a central axis or as an alternate tool for the IoT methodologies.

Based on the calculations made about the compiled bibliometric references in Colombia, that were developed in this study, it was possible to find key words that are generated by the consults of the database Scopus, reflecting the orientation that has had the developed work and the IoT has cooperated in this territory, as it can be appreciated in the Table IV:

TABLE IV

MOST CONSULTED KEYWORDS AT THE IOT RESEARCH LEVEL IN COLOMBIA. SOURCE: SCOPUS

\begin{tabular}{ll}
\hline \multicolumn{1}{c}{ Keyword } & Queries \\
\hline Internet Of Things IOT & 4 \\
Intelligent Transportation System ITS & 2 \\
Precision Agriculture & 2 \\
Wireless Sensor Networks WSN & 2 \\
Artificial Intelligence & 1 \\
Augmented Reality & 1 \\
Benchmarking & 1 \\
Biomedical & 1 \\
\hline \hline
\end{tabular}

In the same way, it can be presented that the referenced terms previously, could generate a web of co-quotations about key words. This will enable, the ease to search and find any file, text and/or author. These words link themselves with the ones that are related previously, as it is shown in the next Fig. 18:

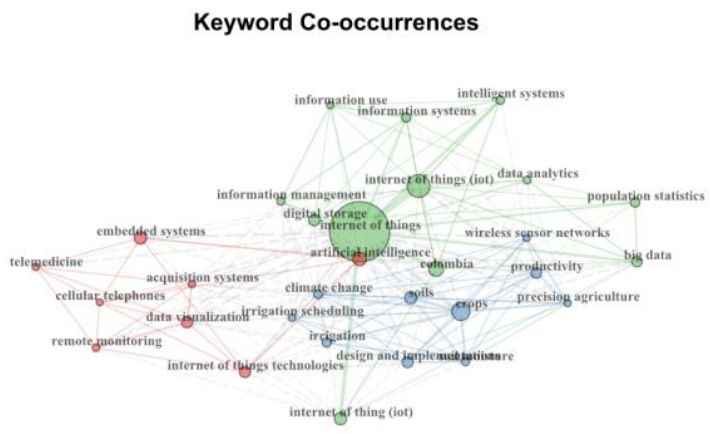

Fig. 18. Network of keywords co-citations at the IoT level in Colombia. Source: Scopus.

In the Fig. 19, it is possible to appreciate that Colombia is considered as standard bearer, similar to Argentina in America regarding to research and production about IoT. This is an important factor for big enterprises and organizations, which could be interested in setting their main branches inside this country, due to it has generated a large technological and logistical unfolding, with results that can warn in the developed files at this part of the worlds about the topic of this study:

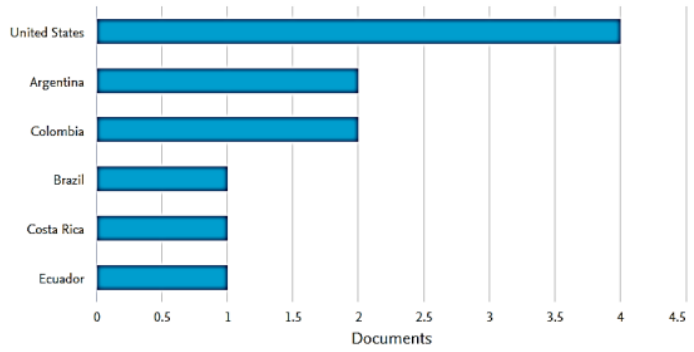

Fig. 19. Productivity of IoT documentation with reference to Colombia and Latin America. Source: Scopus.

\section{CONCLUSIONS}

After reviewing all the information described and detalied about the process of IoT around the world and its influence and development in Colombia, it will be presented the following conclusions.

The possibility of generating mathematical and statistical analysis about the bibliometric data managing supported by different techological tools, which are designed for that reason, acquires a more significant value everytime. It is beacuse, it allows to recognize those who generate publications of scientific topic, obtaining results of graphic, numerical and 
writen types, that are highly reliable for those people and entities that consult and work with them.

There is very tight relation between words and authors that allow the ease of searching files and texts about the IoT, or that quote it inside its procedures and writen, taking a large number of tools that are provided by this techonological model for the techniques improvement and the obtaining of favorable results in the different research. It is very important to highlight the cooperation provided by the Rstudio tool, joined to Bibliometrix library, because they support the data process to a bibliometric reference, being very useful for the statistical analysis in the documentary production field

Likewise, as time goes on, it improves and simplifies the way of making relations among the organizations and entities that recognize IoT as a effective mechanism for the optimization of functions and services, either for a specific group of people or a big community, because of the multiplicity of options that are provided in almost all field in which humanity perform daily, such as medicine, engineering, transport, security, home and environment, among others

To a global level, it is shown that the United States has kept itself as a core country regarding to mediation in research and association inside scientific production related to technology, since it started the documentation of studies about IoT. At the same time, India, outlines itself as a big producer of contents to scientific level (claring out that quantity does not mean quality), followed by China, that has allocated a large amount of economical, academic and infrastructure resources for the techological and methodological development that contributes to the community comfort, making detailed registers of every single activity done.

Talking about Colombia, it is shown that the IoT, is guided towards the community service, as it can be appreciated in the found documentation, which is focused on environmental, transportation, health service, social innovation topics, among others. It is thought that for the next decade, at the same time with Chile, they will become in the countries with the most unfolding in IoT field in South America, due to the relevance that has been awarded to the techological policy currently, and that is in constant spreading and evolution.

\section{REFERENCES}

[1] J. Ardanuy, "Breve introducción a la bibliometría," Universitat de Barcelona. Barcelona, Spain, May. 2019. [Online]. Available: http://diposit.ub.edu/dspace/bitstream/2445/30962/1/breve\%20intro duccion\%20bibliometria.pdf

[2] A. Mcewen and H. Cassimally, "El internet de las cosas: una perspectiva general," in Internet de las cosas: la tecnología revolucionaria que todo lo conecta, 1st Ed. Madrid, Spain: Anaya Multimedia, 2015, pp. 23-24.

[3] A. Mcewen and H. Cassimally, "El internet de las cosas: una perspectiva general," in Internet de las cosas: la tecnología revolucionaria que todo lo conecta, 1st Ed. Madrid, Spain: Anaya Multimedia, 2015, pp. 24.

[4] A. Mcewen and H. Cassimally, "El internet de las cosas: una perspectiva general," in Internet de las cosas: la tecnología revolucionaria que todo lo conecta, 1st Ed. Madrid, Spain: Anaya Multimedia, 2015, pp. 27.

[5] K. Rose, S. Eldridge and L. Chapin, "La internet de las Cosas-Una breve reseña," Internet Society. Fremont, CA, USA, Sept. 8, 2017. [Online]. Available: https://www.internetsociety.org/es/resources/doc/2015/iotoverview

[6] J. Rojas and C. De San Antonio, "Análisis bibliométrico de las publicaciones científicas colombianas en la categoría engineering, multidisciplinary de la base de datos web of science (1997-2009)," DYNA, vol. 77, no. 164, pp. 09-17, Dec. 2010. [Online]. Available: https://revistas.unal.edu.co/index.php/dyna/article/view/25571/260 42

[7] J. Ardanuy, "Breve introducción a la bibliometría," Universitat de Barcelona. Barcelona, Spain, May. 2019. [Online]. Available: http://diposit.ub.edu/dspace/bitstream/2445/30962/1/breve\%20intro duccion\%20bibliometria.pdf

[8] IGI GLOBAL, "What is Science Mapping," IGI Global. Hers, PA, USA, May. 2019. [Online]. Available: https://www.igiglobal.com/dictionary/science-mapping/42948

[9] [9] M. Aria and C. Cuccurullo, "Bibliometrix: An R-tool for comprehensive science mapping analysis," Journal of Informetrics, vol. 11, pp. 959-975, Nov. 2017. DOI: 10.1016/j.joi.2017.08.007

[10] M. Paschou, E. Sakkopoulos, E. Sourla and A. Tsakalidis, "Health Internet of Things: Metrics and methods for efficient data transfer," Simulation Modelling Practice and Theory, no. 34, pp. 186-199, 1970. DOI: $10.1016 /$ j.simpat.2012.08.002

[11] B. Lee, D. Kim, J. Park, K. Park, K. Lee and C. Jeong, "Modulation of surface physics and chemistry in triboelectric energy harvesting technologies. Science and Technology of Advanced Materials," Science and Technology of Advanced Materials, vol. 20, no. 1, pp. 758-773, Jun. 2019. DOI: 10.1080/14686996.2019.1631716

[12] C. González, C. Cárdenas and M. Mendoza, "M2M system for efficient water consumption in sanitary services," DYNA, vol. 85, no. 204, pp. 311-318, 2018. DOI: 10.15446/dyna.v85n204.68264

[13] A. Maz Machado, A. Jiménez Fanjul y M. Villarraga, "La producción científica colombiana en SciELO: un análisis bibliométrico," Revista Interamericana de Bibliotecología, vol. 39, no. 2, pp. 111-119, Feb. 2016. DOI: 10.17533/udea.rib.v39n2a03

[14] E. Barrientos, D. Rico, L. Coronel and F. Cuesta, "Jardín botánico: Prototipo de software para la gestión y divulgación de plantas nativas basado en código QR," Revista Ibérica de Sistemas e Tecnologias de Informação, no. E17, Jan. 2019, pp. 267-282. [Online]. Available: https://www.researchgate.net/profile/Dewar_Rico-

Bautista/publication/331178838_Botanical_garden_Softwareprototype_for_management_and_divulgation_of_native_plants_bas ed_on_QR_code_and_augmented_reality/links/5d09a9a2458515ea 1a70acc5/Botanical-garden-Software-prototype-for-managementand-divulgation-of-native-plants-based-on-QR-code-andaugmented-reality.pdf

[15] AETecno, "IOT en Latinoamérica: los usos y factores que impulsan su expansión," AETecno. Santiago, Chile, Jan. 22, 2019. [Online]. Available: https://tecno.americaeconomia.com/articulos/como-estael-panorama-del-iot-en-latinoamerica 


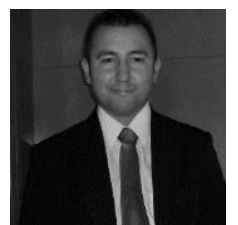

Sergio Hernández Abaunza. He was born in 1984 in the city of Bogotá, graduated as a Technologist in Systematization of data from the District University "Francisco José de Caldas" in 2016. Since 2005 he has worked as a support and infrastructure technician the District Education Secretary of Bogota. He has extensive experience in networks and telecommunications, servers and printers, office automation and hardware and software diagnostics, currently working providing his professional services as a support technician in Colpensiones.

ORCID: https://orcid.org/0000-0001-7971-6682

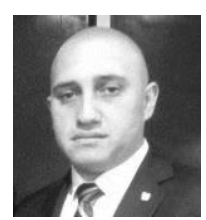

Javier Alberto Ospina Ramos. He was born in 1981 in the city of Bogotá, graduated as a technologist in Systematization of data from the District University "Francisco José de Caldas" in 2014. He has more than 7 years of experience in the educational sector in the area of technology, applying his knowledge in tools of design, tests, analysis and interpretation of data and administration of systems and technological infrastructure.

ORCID: https://orcid.org/0000-0002-2518-5625

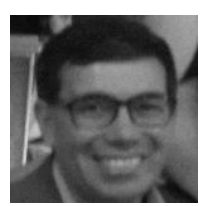

Miguel Ángel Leguizamón Páez. He was born in Tunja (Boyacá) in 1974. He studied Systems Engineering at the University of Boyacá in Tunja, graduated in 1998. Then, in 2000 he received the title of Computer Systems Management Specialist at the University of Boyacá. Later in 2013 he graduated as Master in Information and Communication Sciences at the Francisco José de Caldas District University. He has 19 years of university teaching experience: in the period between 1999 and 2009 he was linked to the Pedagogical and Technological University of Colombia in the city of Tunja. Since 2010 he is a teacher in the field, assistant category at the Francisco José de Caldas District University in the city of Bogotá. Author of 11 articles published in national magazines. His fields of interest focus on management processes at the level of Information and Communication Technologies, distributed systems, Internet of things, Emerging Technologies and university teaching, among others.

ORCID: http://orcid.org/0000-0003-0457-0126 